Professor Mso i politisk og økonomisk idéhistorie Institut for Kultur og Samfund, Aarhus Universitet

\title{
DEN REAKTIONÆRE TANKE
}

I juni 1978 holdt den eksilerede russiske skribent Aleksandr Solzhenitsyn en årsfesttale på Harvard University. Talen adresserer en splittet verden, revet itu af to materialistiske, åndløse kræfter i Øst og i Vest, der begge hylder afguden mennesket og iværksætter forskellige programmer for tilfredsstillelsen af dets materielle, hedonistiske behov. Vesten, siger Solzhenitsyn, er, trods dette fælles forfald, ude af stand til at modstå Sovjetkommunismens ondskab. I Øst er de ved at vinde åndelig styrke gennem deres lidelse, mens Vesten fortfarende svækkes af overdreven legalisme, fri presse, demokrati, individuel frihed og materielle goder. Den "destruktive og uansvarlige frihed har fået uendelig plads." Denne åndelige degeneration gør Vesten ude af stand til at forsvare sig selv. Der er i Vesten "et fald i mod", "en mangel på manddom", der får Vesten til at implodere: "For at forsvare sig selv må man være klar til at dø. Det er der ringe parathed til i et samfund opfostret i det materielle behags kult" (Solzhenitsyn $5,8,15$ ).

Solzhenitsyn indtager en plads blandt den lange række tænkere, der $i$ et par århundreder har fremmanet Vestens snarlige kollaps grundet skørlevned, åndeligt forfald og trangen til at diskutere alt, konfronteret med en dødsvillig og derfor livskraftig fjende, hvis værdier er absolutte, og hvis sult efter dominans er ubundet. Genkendeligheden i Solzhenitsyns tale 
34 KULTUR \& KLASSE $* 126 * 2018$ DET REAKTIONÆRE
35 MIKKEL THORUP

DEN REAKTIONÆRE TANKE små 200 år tilbage i tid og 40 år frem i tid til nutidens anti-muslimske 'stridsmænd' fortæller os et par væsentlige ting. For det første at forfaldet og kollapset altid kan hævdes i vores samfund - forfaldsfortællinger er gavmilde empirisk set - og at det altid bliver det som en tilsyneladende konstitutiv del af det moderne.

Denne artikel handler om den reaktionære tanke, nærmere betegnet reaktionær tænkning, i Vesten de sidste cirka 200 år, som, jeg vil hævde, udgør en forholdsvis stabil tænkning henover perioden og på tværs af lande, tænkere og situationer. Det betyder ikke, at der ikke er afgørende forskelle i tid og rum samt i personer og situationer, men at mit anliggende her er at uddrage fra alle disse en kerne, en grundidé, et sæt af principper og idéer, der samlet set kan kaldes den reaktionære tanke, og som kan hævdes at udgøre den fælles, aktive baggrund for de forskellige slags reaktionære positioner.

Der er ikke skrevet meget eksplicit, hverken selvbeskrivende eller analytisk, om det eller den reaktionære. Det har stået i skyggen af andre begreber som traditionalist, konservativ, kontrarevolutionær og lignende, men der er en række bidrag, værd at nævne, der alle arbejder sig i så nogenlunde samme retning af den reaktionære tanke uden, vil jeg hævde, helt at nå frem til en adækvat og udtømmende forståelse af positionen.

Den amerikanske økonom Albert. O. Hirschman, der døde i 2012, udgav sideløbende med sit økonomiske arbejde en række mere idéhistorisk orienterede bøger, herunder The Rhetoric of Reaction fra 1991, der undersøger, hvad han kalder for konservatismens politisk-økonomiske argumentative strategier i forhold til sociale spørgsmål. Han identificerer tre'reaktionære reaktioner' på kravet om social forandring. Den første og for vores ærinde her vigtigste er 'perverteringstesen': "Enhver bevidst handling for at forbedre et træk ved den politiske, sociale eller økonomiske orden vil kun tjene til at forværre den situation, man ønsker at forbedre". Anderledes formuleret: "Forsøget på at skubbe samfundet i en bestemt retning vil resultere i, at det ganske rigtigt bevæger sig, men i den modsatte retning" (Hirschman $7,11)$. Perverteringstesen låner plausibilitet fra det vigtige samfundsfilo- sofiske begreb om utilsigtede konsekvenser, som bl.a. Adam Smith var med til at formulere en positiv version af $i$ tesen om de utilsigtede, men velstandsfremmende konsekvenser af individuel forfølgelse af egeninteressen (den usynlige hånd). Hvor liberalismen fokuserer på de positive, utilsigtede konsekvenser, fokuserer konservatismen på de negative. Perverteringstesen hævder dog noget langt mere radikalt, nemlig at ikke nok med at forandring og handling med nødvendighed vil medføre utilsigtede konsekvenser; konsekvenserne vil også være de præcist modsatte af intentionen. Det gøres til en naturlov, at intentionel social forandring ikke kan føre til myndiggørelse, men med jernhård nødvendighed vil føre til trældom. Begrebet om utilsigtede konsekvenser er en vigtig påmindelse om det sociales uforudsigelighed og åbenhed, men perverteringstesen lukker det sociale univers igen ved at gøre det forudsigeligt perverst. Hirschman identificerer yderligere to reaktionære argumentationstyper: 'nytteløshedstesen' [futility thesis]: "Forsøget på forandring mislykkes, idet den påståede forandring på en eller anden måde er, var eller vil være overfladisk, en facade, kosmetisk og dermed illusorisk, idet samfundets 'dybe' strukturer forbliver helt igennem uberørte"; samt 'faretesen' [jeopardy thesis]: "Den foreslåede forandring, der måske er ønskværdig i sig selv, indebærer uacceptable omkostninger eller konsekvenser af den ene eller anden art" (Hirschman 43, 81). Disse tre teser er ganske generelle og står til rådighed for mange forskellige politiske positioner. De er del af det reaktionære arsenal i deres hårde udgave, men er også som retoriske strategier ret troløse ideologisk set.

Det samme gør sig i et vist omfang gældende med den amerikanske kognitionsforsker George Lakoff, der i Moral Politics fra 1996 og The Political Mind fra 2008 identificerer to grundfigurer for vores kulturelle dispositioner, den 'omsorgsfulde forælder'-model og den 'strenge fader'-model, hvor vi her kun koncentrerer os om den sidstnævnte, som han også omtaler som den konservative. I modsætning til Hirschman, hvis argumentative model opererer (i hans udlægning) på det instrumentelt-strategiske niveau i en offentlig diskussion, så arbejder Lakoffs model mere på feltet for individuel afkodning af verden ved hjælp af kognitive skemaer, herunder disse to grundmodeller. Den 'strenge fader'-model har som grundidé, at "livet er svært, og verden er fundamentalt set farlig" (Lakoff, Moral Politics 65). Hvis man ikke er konstant årvågen, nøjsom og grænsesættende for sig selv og 
37 MIKKEL THORUP

DEN REAKTIONÆRE TANKE andre, vil menneskets naturlige nydelsessyge forvanske og ødelægge det sociales og det moralskes forudsætning. Enhver afvigelse fra det hierarkisk ordnede system på alle livets områder fører akkumulativt til degeneration og kollaps. Autoritet, grænser, disciplin, vold er derfor nødvendigt, endda moralsk. Livet er en kamp for overlevelse, og det er "gennem konkurrence, at vi opdager, hvem der er moralsk, dvs. hvem der har den rette selvdisciplin og derfor fortjener succes, og hvem der er stærk nok til at overleve og endda trives i en svær verden" (Lakoff, Moral Politics 68). Kamp, anstrengelse, smerte, afsavn, konkurrence er derfor både det sociales vilkår og midlet til succes. Farer og fristelser lurer overalt. Hierarki er naturligt, kampen demonstrerer, hvem der retmæssigt er vinderen. Nogen vil være øverst, andre vil være nederst. "Verden er hierarkisk, og hierarkiet er moralsk" (Lakoff, Moral Politics 69). Den, der ikke kæmper (mod sig selv og mod andre) er svag, amoralsk, naturligt og retmæssigt underlegen og bør ikke kunstigt hjælpes frem eller 'belønnes' for sin svaghed ved at blive beskyttet imod konsekvenserne af den. "Den naturlige orden er en dominansorden, der foregår overalt i verden" og i alle livets forhold (Lakoff, Moral Politics 81). Moralitet er grænser, amoralitet er grænseløshed. Grænserne er faste, evige, naturlige, ikke til forhandling, hvorimod grænseløshed er unaturlig, kunstigt skabt og akkumulativ i bredden og i dybden.

For både Hirschman og Lakoff gælder det, at deres modeller i forhold til vores ærinde her bliver for generelle, at de mere handler om den konservative retorik (i amerikansk politik) end den reaktionære tænkning, og at de er for svagt funderet i historiske opkomster og forløb. De næste to bøger går et stykke i den ønskede retning ved at foretage henholdsvist historiske og filosofiske sammenligninger af reaktionær tænkning i en global kontekst.

Occidentalism, en bog om hvordan vestlige og ikke-vestlige reaktionære ser Vesten, er skrevet af den hollandske historiker Ian Buruma og den israelske filosof Avishai Margalit. De betragter occidentalisme som en vestlig opfindelse, siden eksporteret til resten af verden, og dette eurocentriske fokus også på ikke-vestlige reaktionære er både bogens styrke og svaghed. Styrke, fordi den dokumenterer idémæssige forbindelser mellem vestlige og ikke-vestlige reaktionære samt formår at identificere en globalt forekommende antivestlig figur. Svaghed, fordi alt presses til at passe ind i figuren uden tæt blik for forskelle og lokale oprindelser og med kun ringe interesse i påvirkninger fra ikke-vestlige reaktionære på vestlige. Når det er sagt, så er 'Vesten' eller et billede af eller fantasi om Vesten hos dens modstandere formodentlig et globalt reaktionært træk. 'Vesten' er for reaktionære overalt en hovedfjende, enten direkte fordi de bor deri eller angrebes derfra, eller indirekte via en påstand om vestliggjorte ikke-vestlige samfund (jf. den aktuelle og parallelle fantasi om islamisering af vestlige samfund). 'Vesten', siger Buruma og Margalit, er for dens reaktionære modstandere "en idé, næsten en vision, om et maskinlignende samfund uden en menneskelig sjæl" (Buruma og Margalit 9). Dette lidt for mekanistiske billede afløses i deres bog særligt og væsentligst af en reaktionær billedstorm over byen, metropolen, stedet for det upersonlige. Her er alt og alle til salg. Livet er fordærvet og forfladiget. Det er markedets og bordellets sted. Den prostituerede er i dette billede af 'Vesten' "den mest basale form for urban handel" (Buruma og Margalit 19) eller rettere: sandheden om det urbane liv. Denne modstand mod verden som by er del af en større modernitetskritik eller modoplysning, der anfægter det modernes nivellering og forfladigelse; dets opgør med alle forskelle og hierarkier. Ifølge den franske filosof Pierre-André Taguieff installerer det moderne i sine modstanderes øjne "et inde-imellem og 'hverken det ene eller det andet', det neutrale og det blandede, det at være hjemme overalt og at være hjemme intetsteds, nomaden og kosmopolitten som normative typer" (Taguieff 162). I byen bor det svageliggjorte individ, der hører hjemme alle steder og ingen steder, og som modsvares af heroen, der siger som en Taleban-kriger angiveligt sagde ved starten af Afghanistan-krigen: "De elsker Pepsi-Cola, men vi elsker døden." (Buruma og Margalit 49). Den reaktionære ser byen som lystfuldhedens og grænseløshedens sted og sætter selv vold, afsavn, opofrelse, krig som grænsen mellem sig selv og en verden, der ikke evner at sige nej til sig selv.

Den samme tematik udspiller sig i den britiske litteraturteoretiker Terry Eagletons lille bog Holy Terror fra 2005, der er mindre stærk end Buruma og Margalit på de empiriske nedslag i reaktionens historie, men til gengæld går filosofisk dybere ned i den reaktionære kerneidé. Eagleton, i hans vanlige essayistiske, drillende stil, paralleliserer den texanske og den talebanske fundamentalist, dvs. den kristne og den islamiske reaktionære, og så modstiller han dem begge deres yderste opponent, nihilisten; dem, 
38 KULTUR \& KLASSE $* 126 * 2018$ DET REAKTIONÆRE
39 MIKKEL THORUP

DEN REAKTIONÆRE TANKE der tror mest fuldt og fast versus den, der ikke tror på noget. De to fundamentalister og nihilisten deler noget. De tror, "at intet har nogen mening eller værdi, medmindre det er funderet på jernhårde førsteprincipper. Forskellen er bare, at fundamentalisten tror på sådanne principper, hvorimod nihilisten ikke gør." Nihilisten ser et valg mellem 'leg med sandheden' eller totalitær tvang. Fundamentalisterne ser et valg mellem "anarki og absolut sandhed. De ser ikke, at det er en selvopfyldende tankemåde, fordi for absolutismen vil alt andet end det helt absolutte se anarkistisk ud" (Eagleton 26). Fundamentalister sætter barren for orden så højt, absolutte, evige værdier uden for menneskelig rækkevidde, at enhver faktisk eksisterende orden for dem vil se kaotisk, ugudelig og uordentlig ud. Fundamentalisme, siger Eagleton, "bygger blandt andet på en manglende evne til at acceptere kontingens" (Eagleton 33). Det reaktionære, i Eagletons udlægning, er det mest maniske forsøg, vi kender, på at afvise tilværelsens grundlæggende kontingens - samtidig med at lukningsforsøgene konstant bekræfter samme kontingens ved det menneskeskabte i dem.

Buruma og Margalit samt Eagleton giver os nogle prægnante indblik i mekanismerne bag den reaktionære tanke, men de er begge svage på historisk kontekstualisering, hvilket for så vidt også er tilfældet for den næste og andensidste bog i denne række. Ikke, fordi den ikke prøver at historisere sit materiale, men fordi forfatteren ikke formår hverken historisering eller teoretisering.

Den amerikanske professor i humanistiske videnskaber ved Columbia University, Mark Lilla, har i to bøger forsøgt at bestemme forholdet mellem den intellektuelle og det reaktionære. I The Reckless Mind fra 2001 handler det om den klassiske trope om den intellektuelles totalitære fristelse, der essentielt set er del af en ældre tanke, nemlig at alle forsøg på at ændre verden til det bedre vil lede til det værre, og at intellektuelle er særligt skyldige eller modtagelige for dette. Mere direkte i forhold til temaet er hans The Shipwrecked Mind fra 2016, der handler om politisk reaktion. Den reaktionære, siger han, er ikke konservativ, men radikal. Den reaktionære ser ikke længselsfuldt tilbage, men forfærdet fremad: "apokalyptisk frygt for at træde ind i en ny mørk tidsalder hjemsøger den reaktionære" (Lilla, The Shipwrecked Mind xii). Der er en fortidig idyl som det strukturerende princip i reaktionær tænkning, mener Lilla, en idyl forrådt og forladt af de intellektuelle, men i modsætning til den nostalgiske eller konservative så tror den reaktionære ikke på nogen vej til restauration. Nutiden er en accelererende katastrofe: "En falsk bevidsthed falder snart over det ganske samfund, idet det villigt, endda lystfuldt, bevæger sig mod ødelæggelsen" (Lilla, The Shipwrecked Mind xiii). Den reaktionæres bevidsthed er metaforisk bestemt af skibsbruddet, jf. bogens titel. I tidens strøm ser den reaktionære det gamle samfunds affald flyde forbi. Den revolutionære og den reaktionære deler to grundidéer om tid og historie, nemlig at den går fremad (de er bare uenige, om det er mod lys eller mørke), og at historiens retning er bestemt af menneskelig handling. Den reaktionære er "beskytteren af det, der faktisk skete, ikke profeten om det, der kan blive" (Lilla, The Shipwrecked Mind xiii). Som Lilla rigtigt bemærker, så bestemmer dette den reaktionære som en moderne figur. Hvor den konservative kan falde tilbage i apati, kynisk eller hedonistisk tilbagetrækning fra verden, så er den reaktionære optændt; evindeligt forfærdet over historiske forræderier. Lilla mener dog alligevel at kunne bestemme den reaktionære som en særlig form for nostalgiker, hvilket forvirrer og modsiger alt det ovenstående. Han mener at se i den reaktionære - men er det her den reaktionære tænker eller det reaktionæres tiltrækning for folk overvældet af en verden i konstant forandring? - en konstant opbygning af tabte paradiser. Han siger meget rigtigt om forskellen mellem håb og nostalgi, at håb kan sviges, hvorimod nostalgi er uigendrivelig. Den eksisterer hinsides falsificering og kan derfor tjene som evigt lys i det stormfulde mørke.

Lilla er liberal offentlig intellektuel, hvilket i begge bøger, og i hans seneste bog, The Once and Future Liberal, giver sig udtryk i en forkærlighed for at ækvivalere højre- og venstrefløj til samme reaktionære tænkning (von Eggers). Et næsten perfekt modbillede til ham er en anden amerikansk offentlig intellektuel placeret på venstrefløjen og med en hårdt optrukket definition af den reaktionære som højreorienteret, Corey Robin, der underviser i politisk teori på Brooklyn College, og som i 2011 udgav The Reactionary Mind, genudgivet i betydeligt ændret format i 2018 (jeg benytter mig her af andenudgaven). Robin, der skifter mellem at skrive reaktionær og konservativ, identificerer reaktionens kerne i forsvaret af privilegier, mere præcist i et klassekampsperspektiv, hvor den reaktionære tanke er "den teoretiske stemme for en uvilje imod de underlegne klassers handlekraft" 
40 KULTUR \& KLASSE $* 126 * 2018$ DET REAKTIONÆRE
41 MIKKEL THORUP

DEN REAKTIONÆRE TANKE
(Robin 7). Dynamikken i den reaktionære tænkning har handlet om at "fremme frihed for de højere klasser og begrænsning for de lavere" (Robin 8) under stadigt nye historiske vilkår, hvor grundidéen om naturlig ulighed og dominansens nødvendighed har skullet finde stadig nye udtryksformer, efterhånden som de gamle, f.eks. patriarkalisme eller racisme, mistede overbevisningskraft. Store dele af Robins bog handler om, hvorledes det reaktionære ulighedsprojekt er blevet genformuleret i en egalitær tidsalder, dvs. hvorledes privilegier og uligheder er blevet genformuleret, så de kunne appellere til nye grupper, f.eks. hvorledes biologisk racisme var et væsentligt redskab til at vinde fattige hvide over til en reaktionær dagsorden, for godt nok var de fattige og udbyttede, men i det mindste var de ikke sorte. Den reaktionære tankes historiske dynamik ligger altså ikke i bevægelse i kerneidéen, men i hierarki-argumentets konstante, ydre genformulering. Opgaven er "at appellere til masserne uden at forstyrre elitens magt, eller mere præcist: at tøjle massens energi for at forstærke eller genskabe elitens magt" (Robin 52) En anden væsentlig ting, vi kan tage fra Robins righoldige bog, er observationen af, hvorledes den reaktionære både altid har ret og altid taber, dvs. hvorledes den reaktionære stiliserer sig selv som den evindelige opposition, sandhedens stemme, i det tiltagende mørke, og hvorledes der altid er en påstand om, at de andre, humanisterne, de venstreorienterede, kosmopolitterne, i andre tider jøderne, har været de dominerende siden mindst den franske revolution. Og denne påstand om de andres katastrofale dominans tilsiger også en anden og sidste ting, der i mit vokabular adskiller den reaktionære fra den konservative, nemlig at den reaktionære hårdest kritiserer sine egne, der kujonagtigt har svigtet, ikke turdet stå og slå igennem, og at de forstår sig selv som rebeller (Penny) imod den herskende orden - på vegne af den sande, men undertrykte orden.

En væsentlig forskel mellem de ovenstående arbejder og mit argument nedenfor er, at jeg ikke anser konservatisme som iboende reaktionær, om end det reaktionære som iboende konservativt. De seks bøger opererer alle med for brede kategorier, særligt for 'konservatisme'. Jeg vil snarere sige, at den reaktionære er en konservativ, der ikke vil acceptere den seneste ligheds- og frihedsbølge og som anser netop denne for civilisationens endelige kollaps. Konservatisme derimod kommer i alle mulige udgaver; fra simpel accept og tilpasning til nye vilkår, nostalgisk længsel efter det tabte, defaitistisk-ironisk æstetisering af undergangen, kraftfulde forsøg på genetablering af det tabte samt revolutionære forsøg på at skabe en ny orden. Den anden væsentlige mangel i de ovenstående bøger (med mulig undtagelse af Robin) er den manglende lokalisering af den reaktionære tænknings ophav og afgørende første formuleringer i opgøret med oplysningstænkningen og det, der blev set som dens praktiske realisering i den franske revolution. I det følgende vil jeg derfor koncentrere mig om den reaktionære tænkning, hvis handlingsprincip jeg forstår som observationen af en orden i gang med at kollapse, og hvis idéhistoriske oprindelse jeg finder i modoplysningen (Thorup, Fornuftens perversion).

II

I slutningen af sin tale nævnt ovenfor identificerer Solzhenitsyn ondets rod. Fejltagelsen, siger han, "må være ved roden af selve grundlaget for tænkning i moderne tid. Jeg refererer til det herskende vestlige verdenssyn, der blev født i Renæssancen og som har fundet politisk udtryk siden Oplysningstiden. Det blev basis for politiske og sociale doktriner og kunne kaldes for rationalistisk humanisme eller humanistisk autonomi. ... Det satte den moderne vestlige civilisation på den farlige vej at tilbede mennesket og dets materielle behov" (Solzhenitsyn 16-17). Humanistisk tænkning istandsætter en "total frigørelse fra de kristne århundreders moralske arv med dets store reserver af nåde og ofring" og alle "begrænsninger [på mennesket] blev eroderet overalt i Vesten" (Solzhenitsyn 17).

Den tyske begrebshistoriker Reinhart Koselleck tilbyder os en frugtbar måde at forstå den tids- og historieopfattelse, der ligger under Solzhenitsyns tale. Kosellecks udgangspunkt er, at i det moderne mister fortiden henvisningspotentiale i forhold til fremtiden. Fremtiden bliver den dominerende reference og fortiden dens modbegreb (som i reaktionær, bagudskuende, frygtsom og nostalgisk). Det betyder, at moderne, særligt politiske, begreber peger fremefter, men ikke kun i fremskridtsforstand. Moderne fremtidsbegreber kan også være apokalyptiske, tale om forfald, ødelæggelse og altings endeligt. Når fremtiden bliver ulig fortiden, da kan den både tænkes som bedre og som værre. Væsentligt er det for begge fremtidsevalueringer, at de er resultat af menneskelig handling. Derfor er 
42 KULTUR \& KLASSE $* 126 * 2018$ DET REAKTIONÆRE
43 MIKKEL THORUP

DEN REAKTIONÆRE TANKE selv de mest modernitetskritiske fuldt og helt moderne, da det først er i det moderne, at forfald og sammenbrud som resultat af intentionel menneskelig indblanding meningsfuldt kan tænkes.

Den reaktionære tanke accepterer det modernes grundfortælling som et historisk specifikt brud med fortiden, med overleveret visdom, blind lydighed, underkastelse, til fordel for en autonom, kritik- og spørgsmålsdrevet vej ud af dets 'selvforskyldte umyndighed', som Immanuel Kant kaldte det i 1795. Det reaktionære grundargument er, at denne historiske hændelse igangsatte en uigenkaldelig, selv-accelererende proces, hvormed mennesket fjerner sig stadigt mere fra det menneskelige, det sociale stadigt mere fra det sociales forudsætninger og moralen fra dens grundlag. Den reaktionære tanke betragter skabelsen af det moderne frigørelsesprojekt ikke bare som trist og gråt eller dumt og grimt, men som dén afgørende forbrydelse imod mennesket selv, hvorfra alle andre mere specifikke eller lokale dårligdomme og katastrofer med jernhård nødvendighed kommer.

Den reaktionære tanke er den, der betragter menneskets historieskabende kraft som katastrofens anledning. Det moderne er en usurpation, hvor mennesket indtager en plads, der ikke tilhører det. Men modsat nostalgikeren, der er en tabserfaring uden modstandsvilje, en apatisk accept af det tabtes fortabthed, da er den reaktionære moderne i sin anti-modernitet, derved at vedkommende tager det afgørende syndefald på sig, nemlig den menneskelige skaberkraft, for at bruge det til at indløse en gen-hierarkisering. Den reaktionære accepterer altså, modvilligt, det modernes temporalitet, flugtlinjer ind i fremtiden, som Koselleck kalder det, og dets forankring i menneskelig vilje og handling, men ønsker jf. Robin ovenfor, at omdirigere den moderne, historieskabende energi til ulighedsskabende formål.

Den reaktionære lokaliserer derfor også bruddet i historien konkret og personligt. Det er resultat af et villet oprør imod tingenes sande orden, om det så er gud, konge, biologi, traditionalitet eller andet, der udgør 'det naturlige'. Denne lokalisering af bruddet og dets årsag viser sig i en vestlig kontekst uvægerligt og altid at være oplysningsfilosofferne - evt. med forløbere i Renæssancen eller Reformationen. "Det, vi forstår ved oplysningsfilosofi", fremgik det af den franske ugeavis Journal des débats i 1803, "er dette ugudelige sprog, der lærer folk at foragte deres forfædres religion; dette oprørske sprog, der lærer dem at rejse sig op imod autoriteten; dette korrumperende sprog, der forfærder moraliteten, opmuntrer til synd og fjerner alle passionens hæmninger" (citeret fra McMahon 127). Oplysningsfilosofien er en oprørshandling imod virkeligheden, der har vundet.

Den reaktionære tanke er en refleksion over tabet af magt, jf. Robin, og en massering af tabserfaring, men den er også en historiefilosofi, der arbejder med at bestemme katastrofens opståen, dens skyldige og dens konsekvenser på tværs af samfundsområder samt at afsøge muligheder for at initiere et nyt, ordensgenskabende brud i historien, der herefter skal umuliggøre nye brud.

Lad os nu gå lidt dybere ind i nogle af de essentielle elementer i den reaktionære tænkning, der blev formuleret i årtierne omkring den franske revolution, der for såvel de modernitetsbegejstrede som de -skræmte er sindbilledet på det moderne og overgangen fra en grundlæggende orden til en anden, og hvis argumentative kerne har holdt sig rimelig stabil siden.

\section{III}

Der kan fremskrives en række genkommende argumenter i den reaktionære tænkning, der har holdt sig forbavsende konstante (i lokalt varierende udtryk) fra krigen mod oplysningstænkningen og frem til i dag. De reaktionære argumenter nedenfor har jeg analyseret frem gennem en række læsninger af reaktionære positioner og tænkere (Thorup, Fornuftens perversion; Statens idéhistorie, kap. 13, 14, 16 og 17; Uhørt!; "Når mænd frygter kvinder"). I forbindelse med det arbejde har nedenstående argumenter vist sig igen og igen, enten som eksplicitte argumenter eller som den bagvedliggende tænkning, der gav mening til det sagte. De skal ikke læses som en udtømmende liste eller som den endelige sandhed om den reaktionære tænkning, men snarere som en ressource, hvormed man kan analysere reaktionære tekster og tænkere. Hvis der er gentagelser og overlap punkterne imellem, skyldes det, at de selvfølgelig er forbundne og gensidigt afhængige, idet de er enkeltargumenter i en samlet tænkning. De vigtigste reaktionære argumenter er:

Det moderne er dekadence i acceleration. Alt har sin naturlige plads, men det moderne, oplysningstænkningen især (nu også 68'erne), har forvirret 
44 KULTUR \& KLASSE $* 126 * 2018$ DET REAKTIONÆRE
45 MIKKEL THORUP

DEN REAKTIONÆRE TANKE alle kategorier, opløst alle meningsgivende forskelle. Det moderne er en fortløbende og stadigt accelererende dekadensproces, der fører til et akkumulativt tab af ophøjede værdier, absolutte normer og hellige principper. Mennesket har sat sig selv som dommer over sine anliggender, hvilket i bedste fald skaber naragtige tilstande ("Flere køn end to! Hvor dum kan man være?") og i værste fald katastrofale.

Det moderne er respektløshed. Det opløsende princip i den moderne verden er diskuterbarheden af alle sandheder, viljen til, hvis ikke fanatismen efter, at stille spørgsmålstegn ved alt, kritisere alt, undersøge alt. Det moderne respekterer intet, kender ingen grænser, anerkender ikke det hellige, det ophøjede eller det private. Det moderne taler grimt. Sandhed afløses af meninger. Hellighedens fylde af tom snak.

Sandhedens plads er taget. Når mennesket forsøger at overtage guds eller andre absolutte instansers plads (f.eks. biologiens eller 'tilværelsens konkrethed') og gøre sig til sin egen skaber, da styrter det ned i sine mest degenererede former. Mennesket kan vælte retmæssigheden af tronen, men ikke retmæssigt selv sætte sig på den. Det moderne er en usurpation, en uretmæssig tilranen sig magt, der ikke tilkommer mennesket; en arrogant opløftelse af mennesket til et niveau, det ikke kan håndtere; en frisættelse af et suverænt handlingsrum, som mennesket i sin faldne, syndige, instinktmæssige, svage natur vil forstå som en frisættelse til at gøre hvad som helst.

Sandheden lytter ikke til argumenter. Verden er døv og ubevæget af vores forsøg på at tiltale, anklage eller ændre den. Rationalisme er en overfladisk reduktion af virkelighedens dybde, der søger at oplyse det, der bør forblive ubelyst; at manipulere det, der bør forblive uberørt. Det vigtigste i menneskelivet står udenfor mennesket. De vigtigste sandheder kan ikke begrundes. De giver ikke rationel mening. Det er derfor, de er vigtige. De stiller sig ikke til rådighed for undersøgelse. De står bare. Og derfor kan man stole på dem, forlade sig på dem. Institutioner, fordomme, traditioner, vaner kan i deres konkrete udtryk forekomme tåbelige, gammeldags, undertrykkende, men deres værdi er uforanderligt at stå der og give mennesket rammer, tryghed og forventelighed i en usikker verden.

Tilværelsen er konkret. Dens kategorier er absolutte, faste, afgrænsede. De står uden for historien, dvs. de står og virker uafhængigt af de mennesker, de virker på. Når den reaktionære siger 'historie', så menes ikke den historiske variabilitet og kontingens som følge af menneskelig intervention men derimod noget i retning af uendelighed, altid-været-sådan, og dermed ikke til at ændre for mennesker. Derfor sniger der sig også ofte implicit eller eksplicit biologiske referencer og metaforer ind, der skal sandsynliggøre, at tilværelsens materiale er trægt, stabilt og ikke til forhandling. Det er her, vi finder argumenter om, at 'en mand er en mand og en kvinde er en kvinde og et ægteskab er mellem en mand og kvinde', altså faste, åbenlyse kategorier.

Abstraktion er forvanskning. Tilværelsens konkrethed, den naive eller umiddelbare identifikation mellem tingenes ydre form og deres indre væsen, 'en mand er en mand', modstilles det modernes trang til teoretisering, kritik og abstraktion. Det abstrakte og teoretiske er den forløjede besværliggørelse af verdens tilsyneladenhed. Teoretisering og abstrahering er ikke bare analytiske redskaber til at forstå en kompleks verden, hvis indre kerne ikke altid er lig dens umiddelbare ydre form, men er at forstå som et angreb på verden, på dens fundament i det, der er ligetil, og et angreb på mennesker, hvis tilværelse er umiddelbar. Den ureflekterede sandhed er stærkere end den abstrakte vidensskabelse. Teoretisering er fordummelse.

Alle overskridelser er totale. Enhver overskridelse er katastrofal og akkumulativ. Enhver kritik af forskelle eller uligheder er den direkte, uundgåelige vej til absolut forskelsløshed. Sandheden er absolut; enhver udfordring er altødelæggende. Den, der sætter spørgsmålstegn ved noget, vil have svar, men det svar skaber nye spørgsmål. Og selve det overhovedet at stille spørgsmål er allerede at tvivle. Når først fundamentet for den sociale orden er italesat, vil mennesket rastløst og aggressivt jage svar uden endelig løsning. Der er ingen hvileplads. I det moderne tilfredsstiller intet svar. Der er intet sted hinsides spørgsmål og tvivl, hvor mennesket kan hvile. Det første spørgsmål starter det komplette kollaps.

Frigørelse kan ikke føre til frihed. Virkeligheden i sin konkrethed stritter imod menneskelige forandringsforsøg. Frigørelse fører til menneskelig forvrængning, til altings pervertering, deres omslag i det modsatte af, hvad verdensforbedrerne troede: menneskets omdannelse af sig selv til noget monstrøst, frihedens udarten sig til tøjlesløshed og ensomhed, politikkens kollaps i terror og trældom, fornuftens omvending til ufornuft og oplysningens kollaps i mørke. Virkeligheden er konkret - ofte forstået som religiøs og kan give sig udtryk enten som sand og sund religion eller som perverteret 
46 KULTUR \& KLASSE $* 126 * 2018$ DET REAKTIONÆRE

afguderi, hvor mennesket, pengene, klassen, nyderiet eller andet gøres til afguden. Det moderne tilbeder det forkerte, og det sande modsætter sig.

Eksistensvilkåret er ulighed. Overlevelseskamp er det naturlige. Den stærkeste vil vinde. Nogen skal dominere over andre. Tilværelsens kategorier er asymmetriske. De er hierarkisk ordnede. Forskelle er ikke bare forskelligheder men hierarkier. Der er en naturlig fordeling af oppe og nede. Der er noget kategorisk, evigt, spontant bedre, som det ikke er op til mennesket at vurdere, betvivle eller ændre. Tilværelsens konstitutive ulighed er sat før eller uden for mennesket og determinerer menneskelivet. Derfor skal dominanskampen genaktiveres. De rigtige skal kunne vinde igen, hvilket de ville, hvis ikke de svage kunstigt havde forhindret den naturlige udvælgelse af retmæssige vindere.

Perversionens princip er enshed. Lighed forstås som enshed, som skabelsen af ambivalens, neutralitet, hverken-her-eller-der, midt i mellem, den fremmede, vandreren, kosmopolitten (jøden) som normative typer, der ikke kender forskel på hjemme og ude. Lighed fører til uskelnelighed, til den kvalitative forskels opløsning - nationalt, racemæssigt, socialt, aldersmæssigt, standsmæssigt, kønsligt, økonomisk etc. - i en kvalitetsfri sammenhob af tilfældigheder. Det moderne er begrebsforvirring. Alt, der burde være fast og klart, flyder og udflyder. Lighed er forskelsløshed, et oprør imod tilværelsens naturlige forskelle. Tolerance og forståelse er lig indifference, den manglende evne til at skelne mellem godt og ondt.

Samtiden er falsk lighed. Den naturlige ulighed er i samtiden blevet erstattet af kunstig lighed. Det gode og det slette, det sande og det falske, oppe og nede er blevet sat på niveau med hinanden. Alt er blevet gjort lige gyldigt og dermed ligegyldigt. Dominans- og overlevelseskampen er blevet sat i stå, hvilket skaber gunstige betingelser for det degenererede, det perverse, det mindreværdige, der ellers ikke ville overleve og slet ikke dominere, som det er tilfældet i dag. Samtidens nivellering er nemlig at stille oppe og nede på hovedet. Når det ulige gøres lige, bliver det med reaktionær matematik til det mindreværdiges dominans over det ophøjede. Egalisering ændrer ikke ved kategoriernes asymmetri og hierarki. Det vender det bare kunstigt på hovedet, således at det, der burde lyde nu byder - og heraf flyder en tiltagende pervertering af de menneskelige vilkår fra gudløshed til homoseksualitet til hvad som helst.
47 MIKKEL THORUP

DEN REAKTIONÆRE TANKE

Verden er voldelig. Vold er et konstitutivt vilkår. Verden og livet er at forstå som en uendelig slagmark. Volden kan undertrykkes, men ikke overskrides. Voldens vilkår er også voldens nødvendighed. Menneskelivet er hårdt, brutalt, beskidt og ofte kort. Ondskab findes som aktivt virkende kraft i verden.

Livet er en borgerkrig. Det moderne forstår vold som en skandale, der skal og kan minimeres, hvis ikke afskaffes. Den reaktionære forstår vold som et vilkår, der skal leves med, og borgerkrig er den reaktionæres særlige voldsfantasi (som revolution er den progressives). Borgerkrigen har for den reaktionære en række former, gud versus satan, troen versus kødet i den enkelte, venner og fjender i det sociale. Borgerkrig prioriterer en militant opmærksomhed på den indre fjende - i sig selv og i ens samfund. Forræderi er overalt. Forræderi er borgerkrigsfantasiens vigtigste dynamiske kraft. Nogen svigter. Nogen lukker fjenden ind. Forræderen skal navngives, om den så er syndige tanker eller multikulturalister. Modsat revolutionen, der har sit begivenhedsøjeblik, så er borgerkrigsfantasien en evig fantasi. Den er altid i gang, ofte skjult og uudtalt, men overalt hele tiden, hvis bare man ved, hvor man skal kigge. Borgerkrigsfantasien har - igen i modsætning til revolutionens sætten et før-og-efter - ingen begyndelse eller afslutning. 'Fred' er bare krigens skjulte form. Den indre fjende er altid i gang, gnaver løs i det sociales fundament, svækker modstandskraft, synger sange om overgivelse, åbner skjulte døre på klem.

Undertrykkelse er godt. Verdens voldelighed, erkendelsens begrænsning og kødets svaghed gør, at mennesket er bedst i lænker og på knæ. Frihed er farlig, hvis det ikke er som Edmund Burke kaldte det: en "mandlig, moralsk, reguleret frihed", dvs. en selvbegrænsende, i-sig-selv-kontrol frihed indenfor kald og stand, frihed forstået som lydighed overfor det og de over en. Tvang skal følge mennesket livet igennem. Dem, der ikke kan undertvinge sig selv, skal undertvinges af andre. Voldens konstitutive form gør, at der aldrig kommer et tidspunkt hinsides undertrykkelsens nødvendighed.

Vold er forbedringens yderste grænse. Den reaktionære tænkning udtrykker ofte en fascination, hvis ikke endda en fejring af vold. Krig og vold er antitesen til oplyst fredelighed, og krigeren modstilles kræmmeren. Den volds-massering, som meget reaktionær tænkning udtrykker, skal overbe- 
48 KULTUR \& KLASSE $* 126 * 2018$ DET REAKTIONÆRE
49 MIKKEL THORUP

DEN REAKTIONÆRE TANKE vise om, at kun den naive - og snart døde - tror, livet kan blive fredeligt. Jo mere volden kan fremstilles som naturlig, uundgåelig, endda nødvendig, desto stærkere er argumentet om, at verden ikke grundlæggende kan laves om. Voldens allestedsnærvær skal slukke oplysningens håb.

Nutiden er svag, og dens modstandere er stærke. "Problemet er ikke islams styrke", skrev Iben Tranholm på Facebook d. 8. april 2015, "men de kristnes svaghed". Det moderne er en lang overgivelse, mens dens ydre modstandere er upåvirket af modernitetens selvskade. De er heroiske, frygtelige bæster, der løber storm på det moderne sandslot. Den reaktionære tanke synes altid dårligt at kunne skjule sin fascination af den 'ydre' fjende, den ikke-vestlige, ikke-moderne fjende, der i sit absolutte fjendskab mimer, hvad den reaktionære gerne selv ville have og være. Derfor ligner reaktionære tit hinanden, om de kalder sig kristne eller islamiske eller noget tredje. De er i krig mod det samme dekadente Vesten og hylder de samme principper om blind hengivenhed til en absolut sandhed under dødeligt angreb.

\section{IV}

Den reaktionære tanke er moderne. Den kunne kun opstå i og med det moderne og er med sin argumentation på paradoksal og nødvendig vis lige så meget del af det moderne som det modernes fortalere. Den reaktionære tanke kan i det moderne ikke længere bare forudsættes implicit, men skal formuleres og forsvares i det offentlige. Den reaktionære bidrager til den uendelige snakken, som vedkommende ellers hader ved det moderne.

Der er såvel kontinuitet som forandring i den reaktionære tanke. Afsnittet ovenfor har forsøgt at skitsere det bærende og vedvarende tankegods i den reaktionære tanke, men der er - som endnu en illustration af det modernes påvirkning af sine modstandere - også sket en historisk udvikling af den reaktionære tænkning, idet først genskabelsen af det gamle samfund og siden den totale reorganisering mistede overbevisningskraft. Den reaktionære tanke er én lang historie om tilbagetog og tilpasning, men også om kreative genformuleringer af ulighedens princip i en egalitær tidsalder. Nogle af de væsentlige samtidiggørelser af den reaktionære tanke er:

Afteologisering. Den reaktionære tænkning har sit udgangspunkt i en overbevisning om religionens grundlæggende sandhed og betydning, men såvel modernitetskritikken som det positive projekt bliver i stadigt stigende grad formuleret irreligiøst, ofte med udgangspunkt i biologi eller historie eller endda nytte. Selv de fleste religiøse reaktionære inkorporerer betydelige ikke-religiøse argumenter, mens de alle abonnerer på en ofte vag og implicit idé om det absolutte, nu bare mindre direkte udtalt som Gud.

Fra katastrofe til krise. Også dommedag er blevet afteologiseret. Det er nu oftest kun i metaforisk forstand det ultimative, endelige kollaps fremmanes. Oftere er degeneration den foretrukne samtidsbeskrivelse.

Accept af det modernes institutioner. Der rases stadig imod det modernes institutioner, men nu primært imod, hvad der betragtes som dets forvrængede eller skadelige overdrivelser, dets perverterede udskejelser, snarere end imod selve institutionerne. Kun få vover højt at erklære sig imod moderne naturvidenskab eller kvinders stemmeret, hvorimod man ofte hører beklagelser over deres påståede uheldige sideeffekter eller beklagelige mørke sider. Den reaktionære selvpålagte opgave syntes at have skiftet fra heroisk rasen udefra til beklagelse indefra. Den reaktionære modernitetsafvisning er blevet til en besindet modernitetskritik.

I stor udstrækning er den reaktionære tænkning gået fra at være et verdenssyn til at blive en ressource, et delargument, et billedsprog, der kan bruges til at fordømme uden at forkaste det moderne. Den reaktionære tækning hører konstitutivt med til det moderne, og dets udvikling følger det modernes udvikling. Der masseproduceres derfor til stadighed reaktionær tænkning ud fra ovenstående skabelon, hvorfra det innovative mest består i at udskifte navnene på dem, der nu er de sande slyngler. Der er en helt særlig dovenskab forbundet med den reaktionære tænkning, idet den meget sjældent udviser eller behøver nogen nysgerrighed overfor det, den kritiserer.

Før pennen rammer papiret, er dommen afsagt. Det er den reaktionæres sidste, fortvivlede modstand imod det moderne: for guds skyld ikke undersøge, blind tro er bedre.

MIKKEL THORUP. Professor MSO i politisk og økonomisk idéhistorie ved Institut for Kultur og Samfund, Aarhus Universitet. Har af relevans for denne artikel bl.a. udgivet Fornuftens perversion. 200 års kamp mod fornuftens herredømme (Aarhus Universitetsforlag 2008), Statens idéhistorie (Aarhus Universitetsforlag 2015) samt Uhørt! Idéhistorien læser Trump (Baggrund 2017). Arbejder pt. på en bog om demokratiets aktuelle tilstand. 
50 KULTUR \& KLASSE $* 126 * 2018$

DET REAKTIONÆRE

\section{REACTIONARY THOUGHT}

This article explores the basic arguments of reactionary thinking. I argue that reactionary thought originates in an opposition to the Enlightenment and stayed fairly consistent since then, though with local variations around the core. The article first discusses a number of books on reactionary thought before developing the thesis of the genesis of reactionary thought in and around the Enlightenment, not least the opposition to the idea of man as the sovereign creator of his or her own destiny. Then it goes into detail on the specifics of reactionary thought before ending with a few reflections on the contemporary version of reactionary thought.

\section{KEYWORDS}

DA: reaktionær; anti-moderne; ulighed; dekadence; degeneration; vold

EN: reactionary; anti-modern; inequality, decadence; degeneration; violence

\section{LITTERATUR}

Buruma, Ian og Avishai Margalit. Occidentalism: The West in the Eyes of Its Enemies. New York: Penguin Press, 2004

Eagleton, Terry. Holy Terror. Oxford: Oxford University Press, 2005

Hirschman, Albert. The Rhetoric of Reaction: Perversity, Futility, Jeopardy. Cambridge: Harvard Universirt Press, 1991.

Koselleck, Reinhart. Begreber, tid og erfaring. København: Hans Reitzel, 2007.

Lakoff, George. Moral Politics: What Conservatives Know that Liberals Don't. Chicago \& London: University of Chicago Press, 1996.

Lakoff, George. The Political Mind: Why You Can't Understand 21st Century Politics with an 18th Century Brain. New York: Viking, 2008

Lilla, Mark. The Reckless Mind:Intellectuals in Politics. New York: New York Review Books, 2001.

Lilla, Mark. The Shipwrecked Mind: On Political Reaction. New York: New York Review Books, 2016.

McMahon, Darrin M. Enemies of the Enlightenment: The French Counter-Enlightenment and the Making of Modernity. New York: Oxford University Press, 2001.

Penny, Laurie. "You are not a rebel". The Baffler 11. september 2017. Thebaffler.com/warof-nerves/you-are-not-a-rebel.

Robin, Corey. The Reactionary Mind: Conservatism from Edmund Burke to Donald Trump. Oxford: Oxford University Press, 2. udg., 2018.

Solzhenitsyn, Aleksandr. "A world split apart". Solzhenitsyn at Harvard. Red. Ronald Berman. Washington, DC: Ethics and Public Policy Center. 1980. 3-20.
51 MIKKEL THORUP

DEN REAKTIONÆRE TANKE

Taguieff, Pierre-André. "The Traditionalist Paradigm: Horror of Modernity and Antiliberalism". Why We are Not Nietzscheans. Red. Luc Ferry og Alain Renaut. Chicago \& London: University of Chicago Press, 1997.

Thorup, Mikkel. Fornuftens perversion. Modoplysning og 200 års krig mod fornuftens herredømme. Aarhus: Aarhus Universitetsforlag, 2008.

Thorup, Mikkel. "Når mænd frygter kvinder - Houellebecq, Trump og andre frygtsomme mænd". Kulturo 43 (2017): 96-105.

Thorup, Mikkel. Statens idéhistorie. Magt, vold og politik. Aarhus: Aarhus Universitetsforlag, 2015.

Thorup, Mikkel, red. Uhørt! Idéhistorien læser Donald Trump. Aarhus: Baggrund, 2017.

von Eggers, Nicolai. "Liberalismens skibbrud". Kommunikationsforum 25. november 2016. http://www.kommunikationsforum.dk/artikler/Marc-Lillas-The-Shipwreced-Mind. 
52 KULTUR \& KLASSE * $126 * 2018$ DET REAKTIONÆRE 